\title{
PENINGKATAN KEMAMPUAN PENULISAN SURAT DINAS DI KECAMATAN PONTANG KABUPATEN SERANG, PROVINSI BANTEN
}

\author{
Linda Sari Wulandari ${ }^{1 凶}$ \\ ${ }^{1}$ Program Studi Konstruksi Gedung Jurusan Teknik Sipil \\ Politeknik Negeri Jakarta, Kampus UI, Depok, 16422

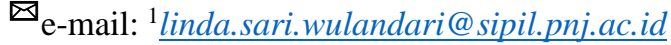

\begin{abstract}
Socialization and training on writing official letters were held in Kubang Puji Village, Pontang District, Serang Regency, Banten Province. The activity was carried out as a result of the collaboration of a team of Indonesian language lecturers from several different departments at the Politeknik Negeri Jakarta to jointly go down to the community to carry out service in the form of socializing and training official letters for staff in the village and sub-district environment. This activity begins with socialization which aims to regenerate public awareness to be able to use the Indonesian language properly and correctly, both orally and in writing, as well as socialize matters related to correspondence material, especially official letters. After that, the lecturer team made a direct approach to the community to carry out technical guidance on writing official letters. The result of this activity is that the community is reminded of the importance of communicating using good and correct Indonesian, as well as increasing knowledge and skills in writing official letters.
\end{abstract}

Keywords-socialization, training, official letter, Pontang District, Serang-Banten

\begin{abstract}
Abstrak
Sosialisasi dan pelatihan penulisan surat dinas dilaksanakan di Desa Kubang Puji, Kecamatan Pontang, Kabupaten Serang, Provinsi Banten. Kegiatan tersebut dilaksanakan hasil kolaborasi di antara tim dosen bahasa Indonesia yang berasal dari beberapa jurusan yang berbeda di Politeknik Negeri Jakarta untuk sama-sama turun ke masyarakat untuk melakukan pengabdian berupa sosialisasi dan pelatihan surat dinas bagi para staf di lingkungan desa dan kecamatan. Kegiatan ini diawali dengan sosialisasi yang bertujuan untuk menumbuhkan kembali kesadaran masyarakat untuk dapat menggunakan bahasa Indonesia dengan baik dan benar, baik secara lisan maupun tertulis, serta menyosialisasikan juga hal-hal yang terkait dengan materi korespondensi, khususnya, surat dinas. Setelah itu, tim dosen melakukan pendekatan secara langsung dengan masyarakat untuk membimbing secara teknis dalam penulisan surat dinas. Hasil dari kegiatan ini masyarakat tersadarkan kembali akan pentingnya berkomuniasi menggunakan bahasa Indonesia yang baik dan benar, serta adanya peningkatan pengetahuan dan keterampilan dalam menulis surat dinas.
\end{abstract}

Kata kunci-sosialisasi, pelatihan, surat dinas, Kecamatan Pontang, Serang-Banten

\section{Pendahuluan}

Surat dinas merupakan surat resmi yang dikeluaran oleh sebuah instansi atau lembaga tertentu untuk keperluan dinas. Surat dinas, umumnya, dikeluarkan oleh instansi pemerintah atau swasta untuk berbagai keperluan. Tujuan surat dinas dikeluarkan untuk pemberitahuan, pengumuman, penugasan, perizinan, keputusan, dan lain-lain kepada staf di instansi atau lembaga terkait.

Selain tujuan dari dikeluarkannya surat dinas, ada pun fungsi dari surat dinas itu sendiri, yaitu (a) sebagai pedoman kerja, misalnya, surat instruksi kerja, surat izin, dan surat keputusan; (b) sebagai alat pengingat, baik kepada pemberi surat maupun penerima surat dinas, sehingga surat dinas harus selalu diarsipkan; (c) sebagai bukti adanya perubahan dan perkembangan pada suatu instansi atau lembaga; serta (d) sebagai alat bukti otentik, terutama surat perjanjian (Finoza, 2006).

Berdasarkan tujuan dan fungsi surat dinas tersebut, dapat diketahui bahwa surat dinas merupakan salah satu 
dokumen penting sehingga sudah seharusnya menggunakan bahasa Indonesia yang baik dan benar sesuai dengan PUEBI (Kemendikbud, 2016). Akan tetapi, suatu instansi atau lembaga yang mengeluarkan surat dinas masih banyak yang serta-merta hanya "membuat" tanpa mengetahui format dan aturan penulisan surat dinas yang dibuat benar atau salah. Instansi/ lembaga membuat surat dinas, biasanya, hanya mengikuti format surat yang sudah tersedia sebelumnya sehingga tidak menyadari bahwa surat dinas yang dibuat tersebut benar atau salah, bahkan tidak sesuai dengan syarat-syarat dalam penulisan surat dinas.

Surat dinas harus dibuat dengan format mengikuti syarat-syarat penulisan surat dinas, seperti (1) format surat dinas dibuat sesuai dengan standar surat resmi dengan format teratur; (2) isi yang dimuat dalam surat dinas harus dibuat dengan singkat, padat, dan jelas; (3) bahasa yang digunakan dalam surat dinas adalah bahasa baku, sopan, dan mudah dimengerti; serta (4) surat dinas harus memberikan citra yang sesuai dengan lembaga/ instansi yang mengeluarkannya. Berdasarkan syaratsyarat penulisan tersebut, faktanya, masih banyak instansi/lembaga yang belum menggunakan bahasa Indonesia dengan baik dan benar dalam penulisan, khususnya surat dinas.

Oleh karena itu, kelompok dosen bahasa Indonesia mengadakan program pengabdian kepada masyarakat dengan judul Sosialisasi dan Pelatihan Penulisan surat dinas pada Masyarakat Kecamatan Pontang, Kabupaten Serang, Banten. Masyarakat dalam hal ini adalah staf yang bekerja di lingkungan Kecamatan Pontang agar mampu Metode Pengabdian

\section{Pendekatan}

Kelompok dosen bahasa Indonesia Politeknik Negeri Jakarta mengikutsertakankan dosen-dosen membuat surat dinas dengan format dan kebahasaan yang baik dan benar untuk peningkatan pelayanan administrasi publik.

Kecamatan Pontang terdiri dari sebelas desa, yaitu Desa Sukajaya, Desa Sukanegara, Desa Kalapian, Desa Keserangan, Desa Pulo Kencana, Desa Linduk, Desa Kubang Puji, Desa Singarajan, Desa Pontang, Desa Wanayasa, dan Desa Domas. Berdasarkan data Badan Pusat Statistik (2018) Kecamatan Pontang Kabupaten Serang, Banten, selain desa-desa tersebut, di Kecamatan Pontang juga terdapat beberapa institusi/lembaga pemerintahan, seperti UPTD Pendidikan, UPTD Pertanian, Puskesmas, Kantor Urusan Agama, UPTD KB, Polsek, Koramil, UPTD PDAM, dan UPK PNPM (Badan Pusat Statistik. 2018. Kecamatan Pontang dalam Angka. Serang: Badan Pusat Statistik Kabupaten Serang).

Berdasarkan hal tersebut, seluruh staf yang bekerja di lingkunagn Kecamatan Pontang sudah seharusnya dapat mengerti dan membuat surat dinas dengan baik dan benar, terutama dalam melayani administrasi bagi masyarakat di Kecamatan Pontang, sehingga kualitas pelayanan terhadap masyarakat menjadi lebih baik. Oleh karena itu, penulis merasa perlu melakukan sosialisasi dan pelatihan penulisan surat dinas kepada para staf di Kecamatan Pontang supaya para staf mengerti dan dapat membuat surat dinas dengan baik dan benar sesuai dengan kaidah kebahasaan bahasa Indonesia sehingga akan meningkatkan pula pelayanan administrasi kepada masyarakat, terutama yang berkaitan dengan surat dinas.

bahasa Indonesia di seluruh jurusan untuk melaksanakan kegiatan "Sosialisasi dan Pelatihan Penulisan surat dinas pada Masyarakat Kecamatan Pontang, Kabupaten Serang, Banten”. 


\section{Prosedur Kerja}

a. Persiapan

1) Menemui Camat Kecamatan Pontang, Banten dan Kepala Desa Kubang Puji untuk meminta izin melakukan kegiatan "Sosialisasi dan Pelatihan Penulisan surat dinas pada Masyarakat Kecamatan Pontang, Kabupaten Serang, Banten".

2) Mengirim Surat Pemberitahuan kepada Kepala Desa Kubang Puji, Camat Kecamatan Pontang dan Walikota Banten dan meminta izin untuk melaksanakan kegiatan "Sosialisasi dan Pelatihan Penulisan surat dinas pada Masyarakat Kecamatan Pontang, Kabupaten Serang, Banten".

3) Mendata masyarakat/staf di lingkungan Kecamatan Pontang yang berminat mengikuti pelatihan penulisan surat dinas.

b. Pelaksanaan

a) Kegiatan akan dilaksanakan selama satu hari yaitu: 15 November 2019 . b) Kegiatan sosialisasi dilaksanakan Kantor Desa Kubang Puji, Kecamatan Pontang, Serang, Banten.

c) Kegiatan praktik penulisan surat dinas dilaksanakan di Kantor Desa Kubang Puji, Kecamatan Pontang, Serang, Banten.

d) Pelaksanaan sosialisasi dan pelatihan penulisan surat dinas pada masyarakat Kecamatan Pontang, Kabupaten Serang, Banten" dilaksanakan oleh dosen bahasa Indonesia Politeknik Negeri Jakarta.

e) Bidang pelatihan adalah dasar-dasar penulisan surat dinas dengan baik dan benar sesuai dengan kaidah Bahasa Indonesia.

f) Setiap peserta dilengkapi buku Pedoman Umum Ejaan Bahasa Indonesia (PUEBI) dan modul Pedoman Penulisan Surat Dinas.

g) Praktik penulisan surat dinas dengan baik dan benar sesuai dengan kaidah Bahasa Indonesia oleh para peserta sesuai dengan tugasnya masingmasing.

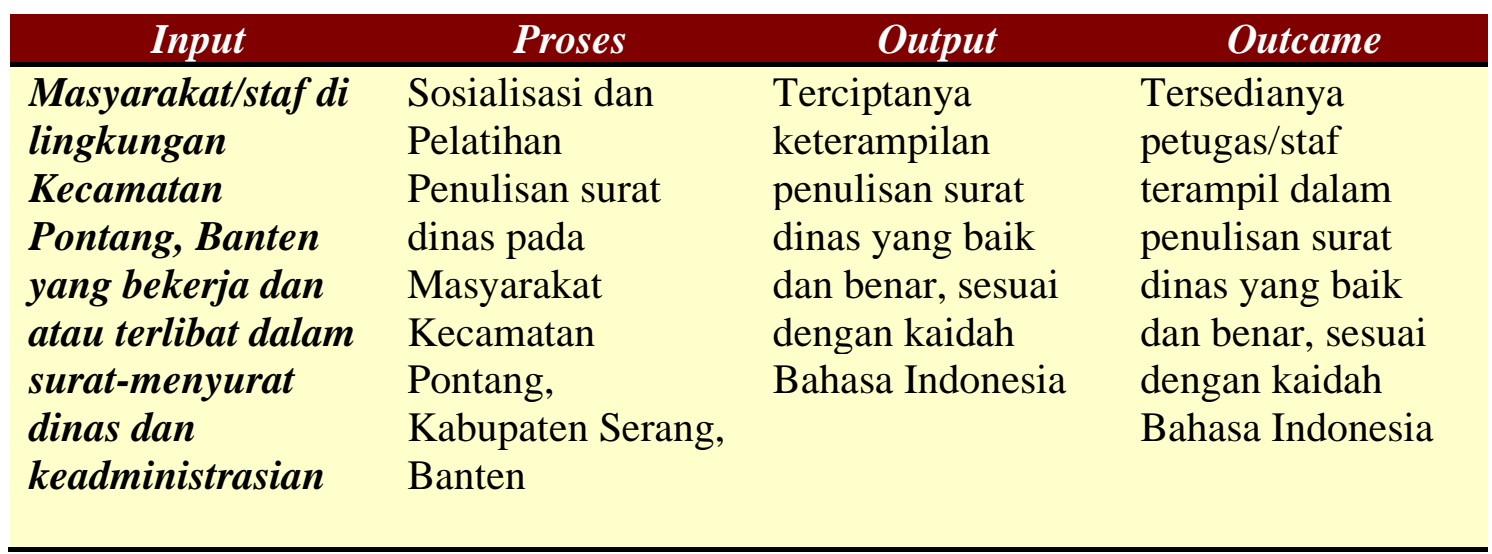

Gambar 1. Diagram Proses

\section{Hasil Dan Pembahasan}

Kegiatan pengabdian ini merupakan kegiatan pengabdian masyarakat dari kelompok dosen bahasa Indonesia Politeknik Negeri Jakarta yang pertama kali dilakukan. Pengabdian masyarakat kelompok dosen ini dilaksanakan pada Jumat, 15 November 2019, di Aula Kantor Desa
Kubang Puji Kecamatan Pontang Kabupaten Serang, Banten.

Dalam kegiatan pengabdian kepada masyarakat, dosen-dosen bahasa Indonesia di Politeknik Negeri Jakarta berjumlah 6 orang, serta ada tambahan 1 orang dosen Pendidikan Kewarganegaraan, sedangkan mahasiswa internal PNJ yang terlibat berjumlah 2 orang, serta mahasiswa 
eksternal dari daerah setempat berjumlah 1 orang. Peserta yang hadir untuk mengikuti kegiatan ini berjumlah sekitar 20 oarang, yang berasal dari staf desa dan kecamatan, serta beberapa karang taruna daerah setempat.

Sosialisasi dan pelatihan penulisan surat dinas dilakukan dengan memberikan materi mengenai pengertian surat, jenis-jenis surat dinas, serta format surat dinas.

Surat dinas harus dibuat dengan format mengikuti syarat-syarat penulisan surat dinas, seperti (1) format surat dinas

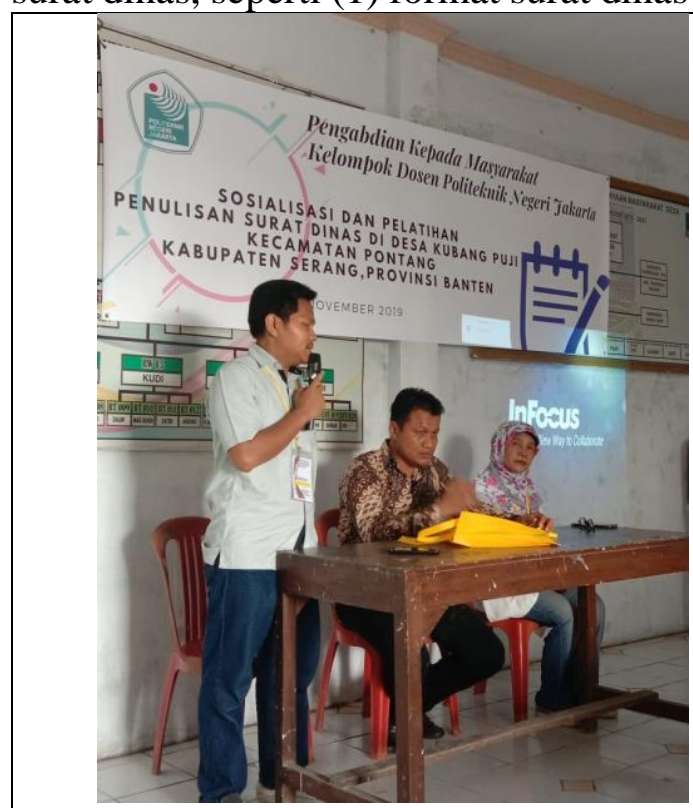

Pembukaan oleh Bapak Asep, perwakilan kelompok dosen

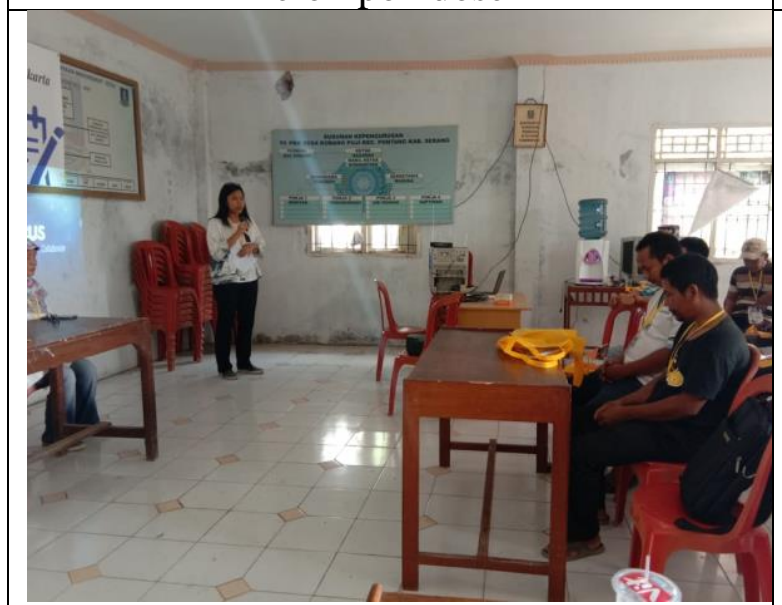

MC acara Ibu Erlyn dibuat sesuai dengan standar surat resmi dengan format teratur; (2) isi yang dimuat dalam surat dinas harus dibuat dengan singkat, padat, dan jelas; (3) bahasa yang digunakan dalam surat dinas adalah bahasa baku, sopan, dan mudah dimengerti; serta (4) surat dinas harus memberikan citra yang sesuai dengan lembaga/ instansi yang mengeluarkannya.

Gambar berikut menunjukan foto kegiatan sosialisasi dan pelatihan surat dinas kepada masyarakat di lingkungan Kecamatan Pontang.

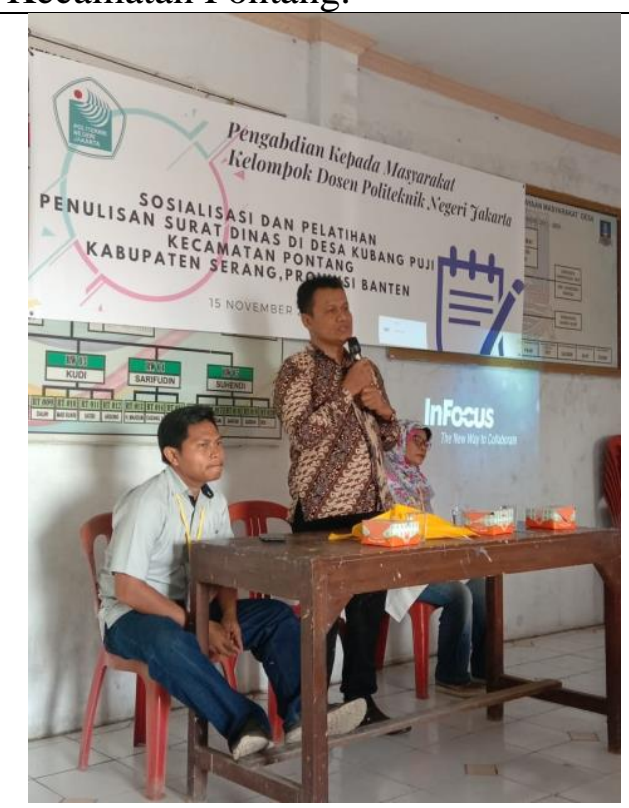

Sambutan oleh Kepala Desa Kubang Puji, Bapak Ade Suhada

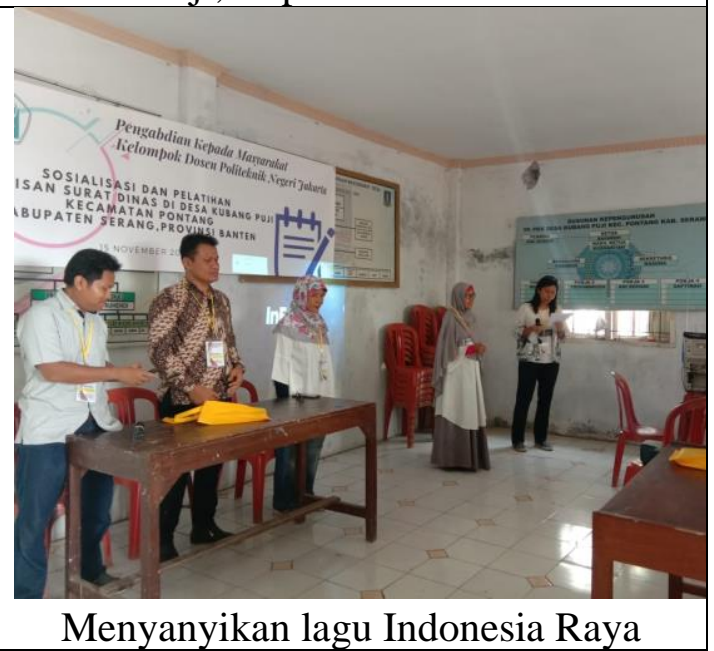




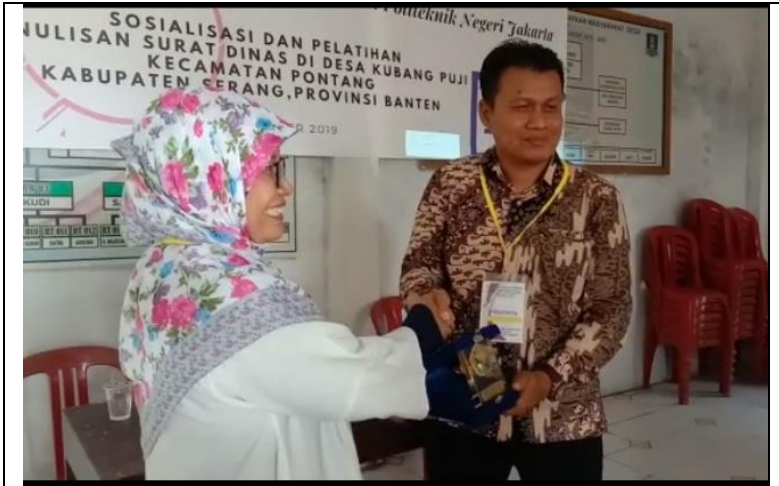

Pemberian plakat PNJ kepada Kepala Desa Kubang Puji

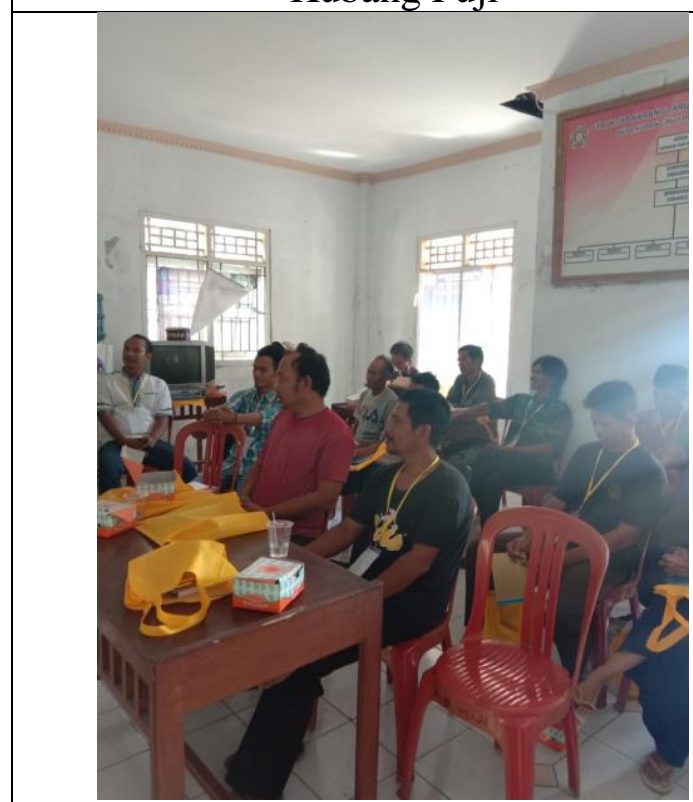

Peserta sosialisasi dan pelatihan surat dinas

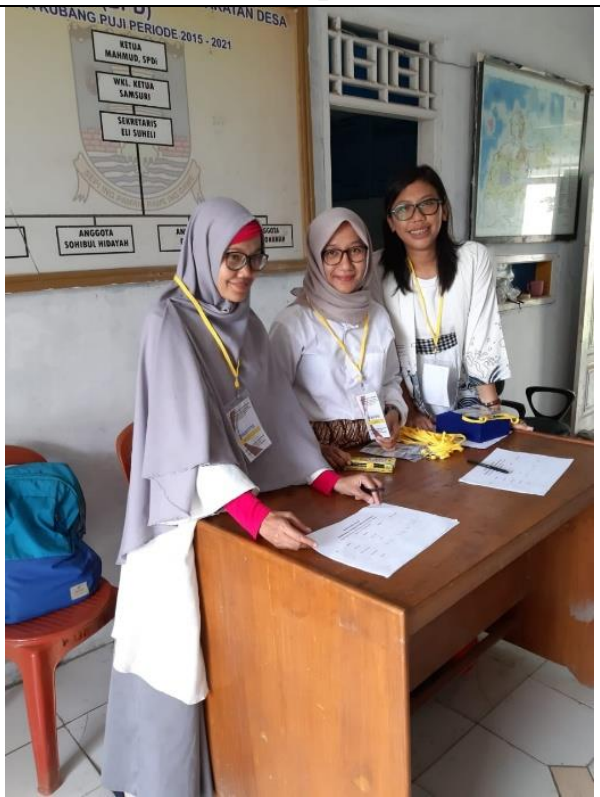

Panitia, dosen bahasa PNJ, pengabdian

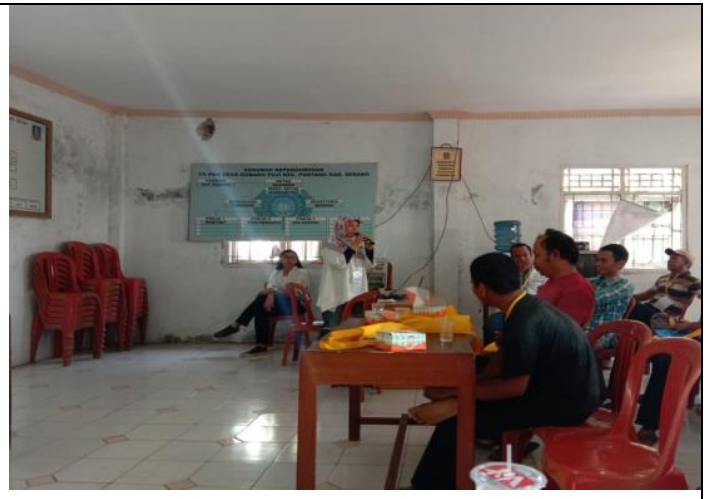

Pemaparan materi sosialisasi dan pelatihan surat dinas

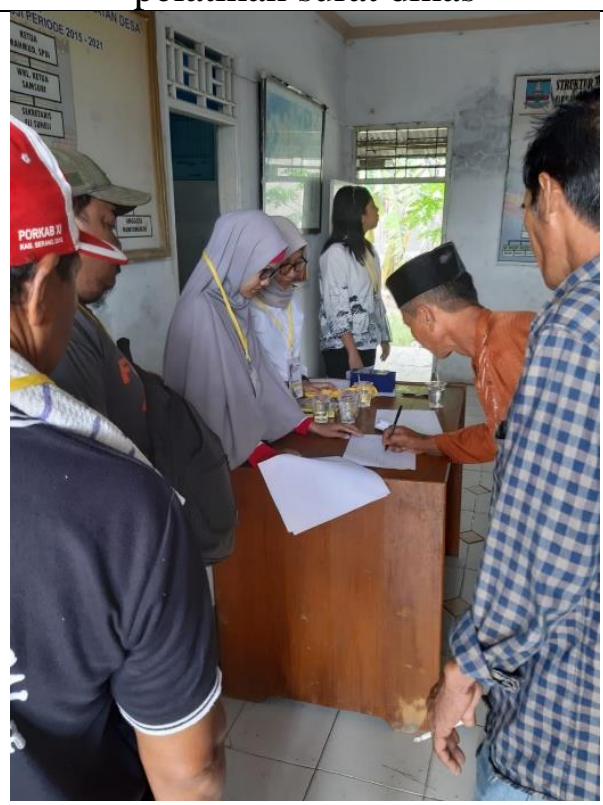

Registrasi peserta

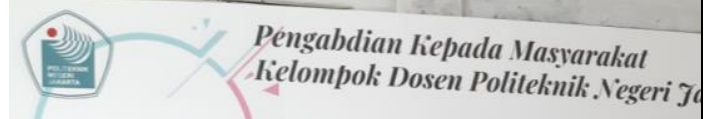

SOSIALISASI DAN PELATIHAN PENULISAN SURAT DINAS DI DESA KUBANG PUJI

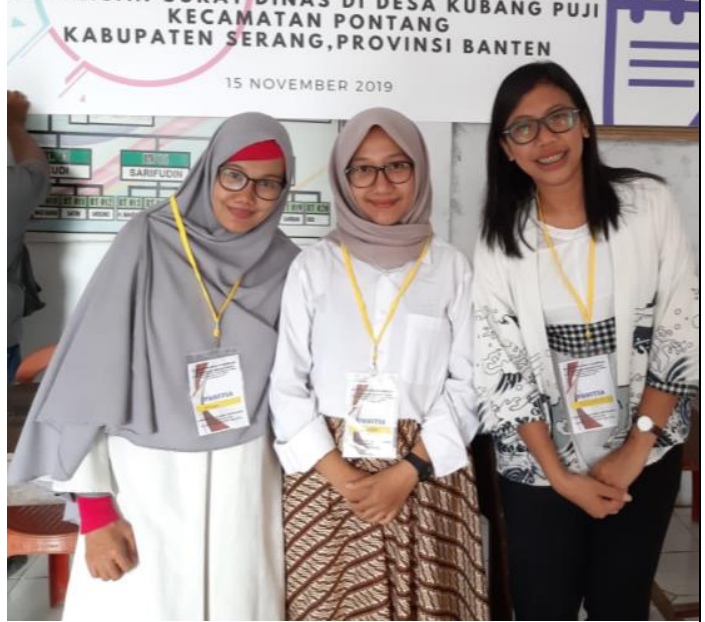

Panitia, dosen bahasa PNJ, pengabdian 


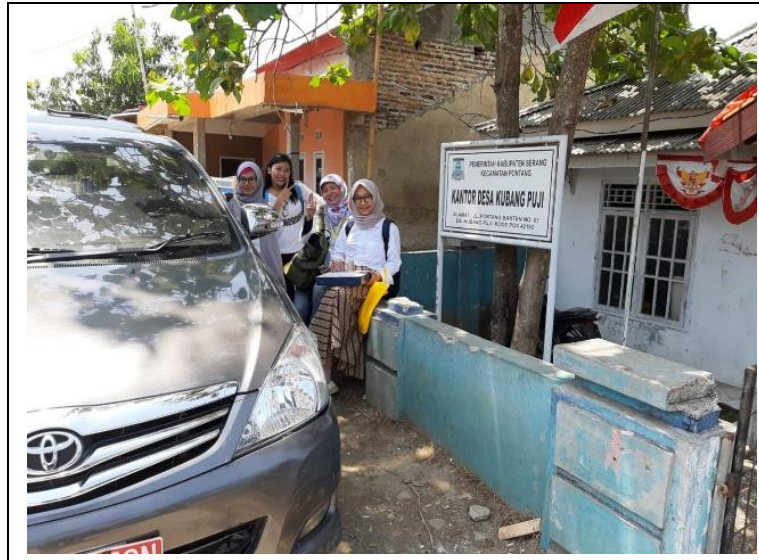

Depan Kantor Desa Kubang Puji, lokasi pengabdian

Gambar berikut menunjukkan peserta dan panitia pengabdian masyarakat

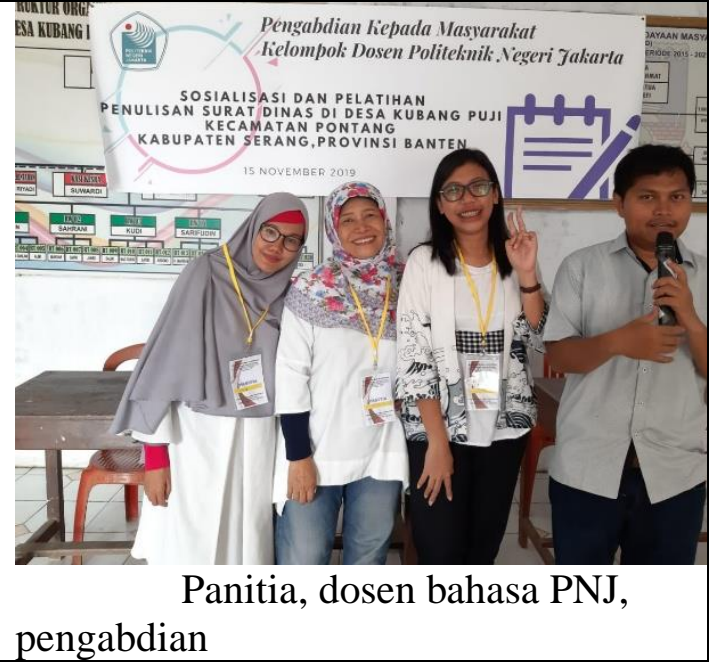

kelompok sosialisasi dan penulisan surat dinas.

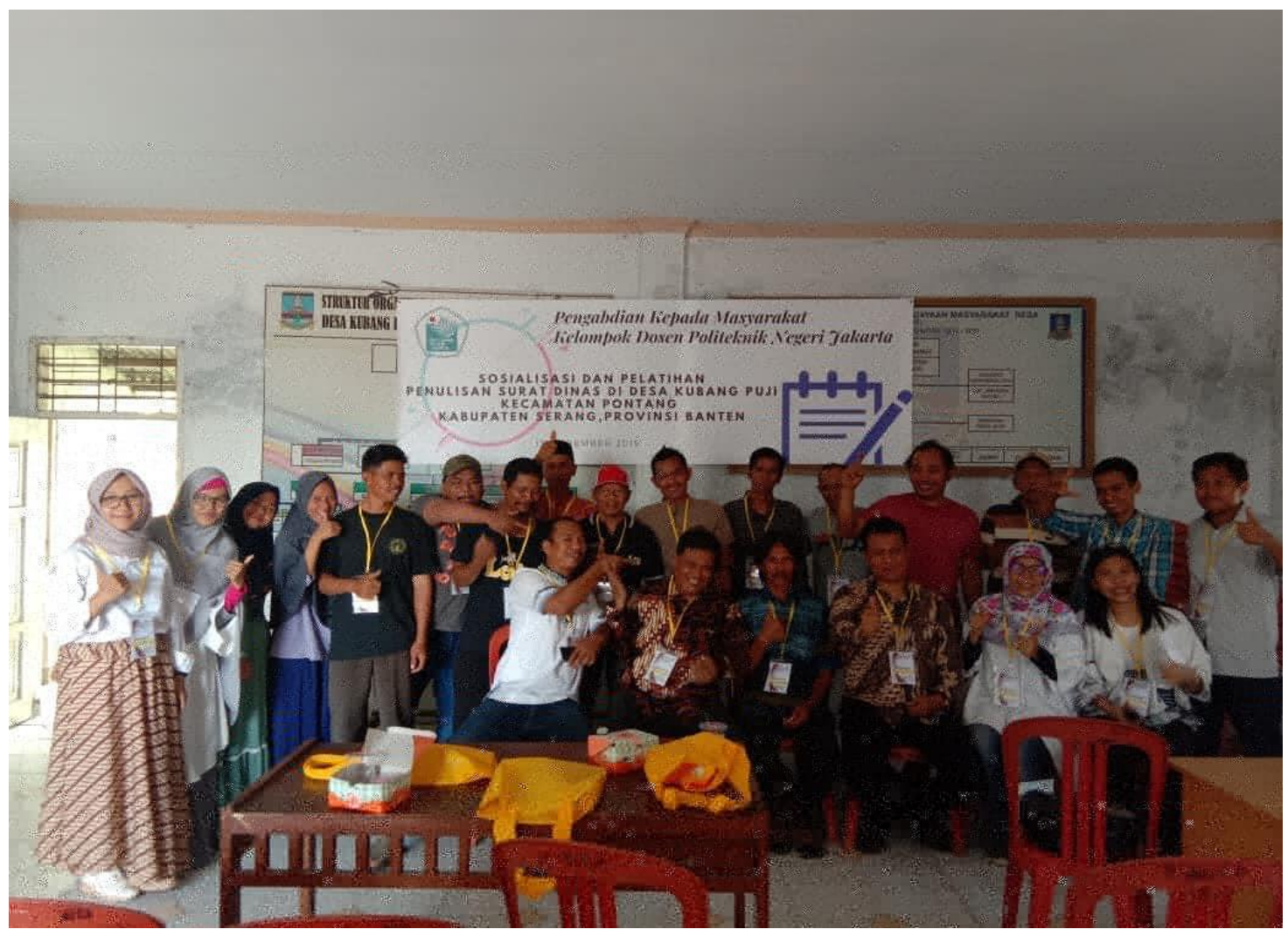

Gambar 2. Peserta dan Panitia Pengabdian Masyarakat

\section{Kesimpulan}

Kegiatan pengabdian seperti ini adalah langkah awal kelompok dosen bahasa PNJ untuk melakukan sosialisasi dan pelatihan surat dinas kepada masyarakat di luar Kota Depok. Kegiatan seperti ini dapat mendorong para staf desa, bahkan kecamatan, serta masyarakat untuk dapat berbahasa Indonesia secara baik dan benar, khususnya, penulisan surat dinas. Dengan kegiatan pengabdian masyarakat ini, peserta bisa mendapatkan ilmu yg bermanfaat dalam penulisan surat, khususnya, surat dinas. 


\section{Saran}

Kegitan semacam ini tidak cukup berhenti pada kegiatan ini saja. Masyarakat di Desa Kubang Puji ratarata bermata pencarian sebagai petani dan penambak sehingga jika program pengabdian bisa berlanjut dapat dilakukan pada bentuk pengarahan dan juga pelatihan kepada masyarakat di sektor pertanian dan pertambakan karena mayoritas penduduk di sana bermatapencarian sebagai petani dan penambak.

\section{Ucapan Terima Kasih}

Penulis mengucapkan terima kasih kepada Kepala P3M yang telah memberi dukungan berupa biaya terhadap keberhasilan pengabdian ini.

\section{Daftar Pustaka}

[1] Badan Pusat Statistik. (2018). Kecamatan Pontang dalam Angka. Serang: Badan Pusat Statistik Kabupaten Serang.

[2] Finoza, L. (2006). Aneka Surat Sekretaris dan Bisnis Indonesia. Jakarta: Diksi Insan Mulia.

[3] Kemendikbud. (2016). Pedoman Umum Ejaan Bahasa Indonesia. Jakarta: Badan Pengembangan dan Pembinaan Bahasa Kementerian Pendidikan dan Kebudayaan. 